\title{
THE CORRELATION BETWEEN THE OPEN SPACE EXISTENCE AND BUILDING HEIGHT ON JAKARTA'S ROADS
}

\section{Made Anggita Wahyudi Linggasani ${ }^{1}$, Vika Haristianti ${ }^{2}$, Stefani Natalia Sabatini ${ }^{3}$}

${ }^{1}$ Architecture Dept., Universitas Warmadewa, Denpasar, Indonesia

${ }^{2}$ Interior Design Dept., Universitas Telkom, Bandung, Indonesia

${ }^{3}$ Architecture Dept., Universitas Kristen Duta Wacana, Yogyakarta, Indonesia corresponding author: linggasani@warmadewa.ac.id

$\begin{array}{cccc} & & \text { Article History: } & \\ \text { Received: } 19 \text { April } & \text { Revised: } 26 \text { April } & \text { Accepted: } 28 \text { Apri; } & \text { Available online: } 30 \text { April } \\ 2020 & 2020 & 2020 & 2020\end{array}$

\begin{abstract}
Jakarta, the capital of Indonesia, is indirectly experiencing rapid development in building construction. As a result, day by day Jakarta is becoming crowded by buildings and eventually forced to negate the existence of open space in one site. This condition is also experienced in Jalan Jaksa (a tourism area) and Jalan Wahid Hasyim (at the end of Jalan Jaksa). Both of these roads seem lacking in considering the existence of local development regulations that should pay attention to the rules of the building border line (GSB) and the road border line (GSJ). To find out the truth, the research will be conducted through the method of observing the city face on both roads. The analytical method used is correspondence analysis using variable height of buildings and the existence of open space in each building. Based on the results of the analysis, it was found that there are still many buildings that not applying the rules of the building border line (GSB) and the road border line (GSJ). Especially for one-story buildings that tend not to have a yard (open space area) on the front as a form of implementing the GSB / GSJ rules. Meanwhile, multi-storey buildings (2-storey, 3-storey, etc.) here in general have a yard in the front. The existence of the yard is actually important to be provided as an open space, because it can accommodate human activities and needs, such as a parking area or an assembly point when a disaster occurs.
\end{abstract}

Keywords: Open space existence, building height, development regulation

\section{Introduction}

Jalan Jaksa, located in the Kebon Sirih area, Central Jakarta, has been known for almost 30 years as one of the tourism attractions and inexpensive lodging places for foreign tourists (tourists). Even Jalan Jaksa is better known than some tourism attractions in Jakarta. While Jalan Wahid Hasyim is a road that located at the end of Jalan Jaksa which is a major road (public road) and is dominated by tall buildings with more than 1 floor.

Both of these roads, as they are in the center of Jakarta tend to have a high level of population density. This automatically raises the level of activity and the needs for buildings that are higher and denser too. With the increasing needs of the people in the capital, this often causes people to ignore government regulations in terms of development. The physical condition of many buildings on Jalan Jaksa and Wahid Hasyim, are not having a courtyard (open space area) in their own area. In fact, there are still buildings that do not match the proportion and scale of the height of the building to the existence of the courtyard. This condition is quite alarming if imagined when a disaster will occur in a building that does not have an open space area (courtyard). 
Seeing this directly in the field, makes the writer interested in conducting in-depth research to see the condition of the face of the city on these two roads related to the level of protection against disasters. Based on the data found in the field, a more specific analysis will be carried out on the height of the building and the existence of the courtyard (open space area). This analysis aims to describe in more detail of the relationship that occurs between the height of the building and the existence of the courtyard (open space area) on each site along the road section. The selection of these two variables is thought to be able to explain its correlation.

\section{Theoretical Framework}

\subsection{ASPECT AND ROLE OF YARD EXISTENCE (OPEN SPACE)}

Open space is basically in the form of empty space which is very useful for accommodating various activities in it. This open space is also referred to as an architectural space without a roof, where this space is bounded by land (earth) as a parable of the floor, buildings and natural boundaries around it are likened to walls, then there is a sky which is likened to the roof (Iswanto, 2006).

Open space in question is that it can be in the form of green open spaces, parking areas, parks, courtyards, fields, and others. In addition, open space must essentially have 3 criteria (Ibid in Iswanto, 2006):

- Meaningful: able to provide meaning to the local community, both individually and in groups.

- Responsive: able to respond to all user needs and accommodate activities in the open space.

- Democratic: able to accept the presence of various layers of society freely without any discrimination As for some important things that are also related to the proportion and scale of an open space (Shirvani, 1985), they are:

- Building Height: as an element of city skyline.

- Building Tendency: Control of tendency from wind and sunlight conditions. The results of the shading control are articulation forms of the surface level and shape of the building. Control of sunlight and wind will affect the height of buildings, setbacks, conditional heights, sun angles, viewpoints, and spaces between buildings

- Building Floor coefficient (KLB): maximum number of floors based on allowed designation and capacity intensity.

- Building Base Coefficient (KDB): the area of land or footprint that is closed is proportional to the overall area. KDB is intended to provide sufficient open land in the area.

- Building Border Line (GSB): the distance of the building to the axle that provide a clear view of the road user.

\subsection{ROLE AND SETTING OF CONSTRUCTION}

Definition of Building Height according to the Department of Public Works (1996: 22-27) Jakarta (in Hendrojogi, 2008) is Building Height (TB) or building elevated is the number of full floors in a building calculated from the ground floor to the top of the building roof which is stated in meters. TB can also be interpreted as a number calculation that limits the height of the building which can be a layer / level of the building in units of height (meters). Tall buildings tend to follow the level of intensity of activity in a particular area, especially in the city center. City centers tend to have buildings that are close to the surrounding buildings and mostly are tall buildings. In principle, tall buildings are only permitted on land uses that require high intensity of space use, such as land for commercial activities and services (Hendrojogi, 2008).

In the regulation of the Department of Public Works (1996: 22-27) Jakarta (in Hendrojogi, 2008), the building height regulation is expected to:

- An optimal use of land occurs in order to create safety and environmental comfort.

- Development occurs in accordance with the carrying capacity of the land.

- Landmark area can stand out.

- Building harmony and the environment occurred.

In creating environmental safety and comfort as stated in the building height rule above, the building should be made into a tenuous building and pay attention to the relation between GSB (Building 
Border Line), KDB (Building Base Coefficient), KLB (Building Floor Coefficient), and TB (Building Height) is good as in Figure 1

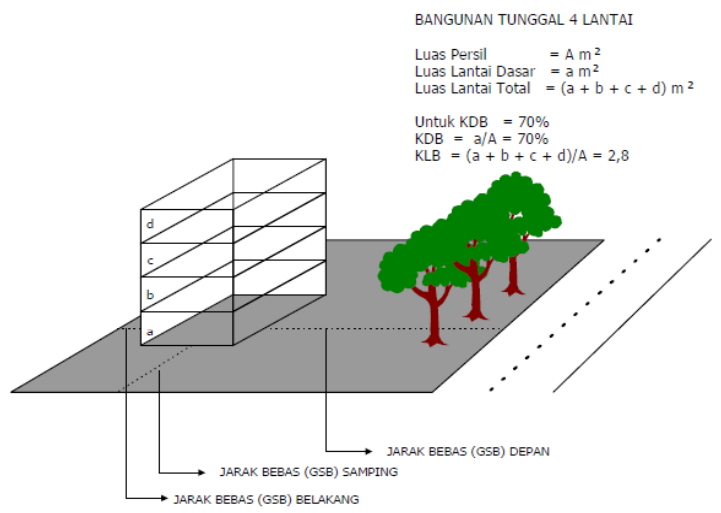

Figure 1. Relationship between GSB, KDB, KLB, and TB for tenuous buildings

(Source: Hendrojogi, 2008)

As for several regulations related to Building Border Line (GSB) and Road Border Line (GSJ) based on the Regional Regulation of the Special Capital Region of Jakarta Number 7 of 1991 concerning Buildings in the Special Capital Region of Jakarta at:

- Article 1 point $n$ : Building Borderline, hereinafter abbreviated as GSB, is a line that should not be crossed by the building plan towards the GSJ (Road Borderline) stipulated in the city plan;

- Article 95 point (2): The height of the boundary in the GSJ and between GSJ and GSB in residential buildings is a maximum of $1.50 \mathrm{~m}$ above the ground surface, and for non-residential buildings including industrial buildings a maximum of $2 \mathrm{~m}$ above the land surface area.

In addition, according to Article 34 of the DKI Jakarta Provincial Regulation No. 7 of 2010, open space between the GSJ and GSB can be used as an element of reforestation and / or rainwater catchment areas and other public interests. The determination of GSB itself is based on considerations of safety, health, comfort, and harmony with the environment and the height of the building as stated in Permen PU No: 29 / PRT / M / 2006 concerning Guidelines for Building Technical Requirements.

\section{Methods}

The research method used is a mixed-method between qualitative and quantitative methods. In the initial stages of this study using qualitative methods through direct observation to the field and then identifying key words from objects on the field. The next stage, this study uses a quantitative method by conducting correspondence analysis to see the relationship between the keywords found.

\section{Results and Discussions}

Based on the results of the field survey, in Jalan Jaksa and Jalan Wahid Hasyim Jakarta, several key words have been found which will be selected into two selected keywords for quantitative analysis. The key words are found through physical condition on both roads. The physical condition is displayed in the form of image data that shows the height, the function of the building, building materials, style, the existence of the courtyard (which means open space area), the presence of signage, and others. Finally two keywords were chosen for in-depth research. The two keywords are "Existence of the Open Space and Building Height". The analyisis described as follows:

\subsection{Analysis of Physical Conditions on Both Roads}

The first stage, a thorough analysis is carried out on the physical condition on both roads. Then, to determine the physical condition of the two roads, the distribution analysis and dendogram analysis of the height of the building and the existence of the open space in each site are carried out.

The results of the analysis of the distribution at the height of the building showed that 2-4 storey buildings classified as medium rise buildings were more dominant than the 1-storey building (low rise) and multi-storey buildings ( $>5$ floors) which included in the high rise category. From the data obtained, there are 98 sites which consist of medium rise buildings with 46 buildings, high rise buildings (> 5 floors) 
with 13 buildings, 35 buildings by low rise buildings and 4 vacant lands (see Figure 2). While the result of the distribution analysis on the open space existence shows that the sites that are on the road are dominated by the availability of the open space area compared to the unavailability of the open space area. There are 77 sites has open space area and 21 sites does not has it (see Figure 2).

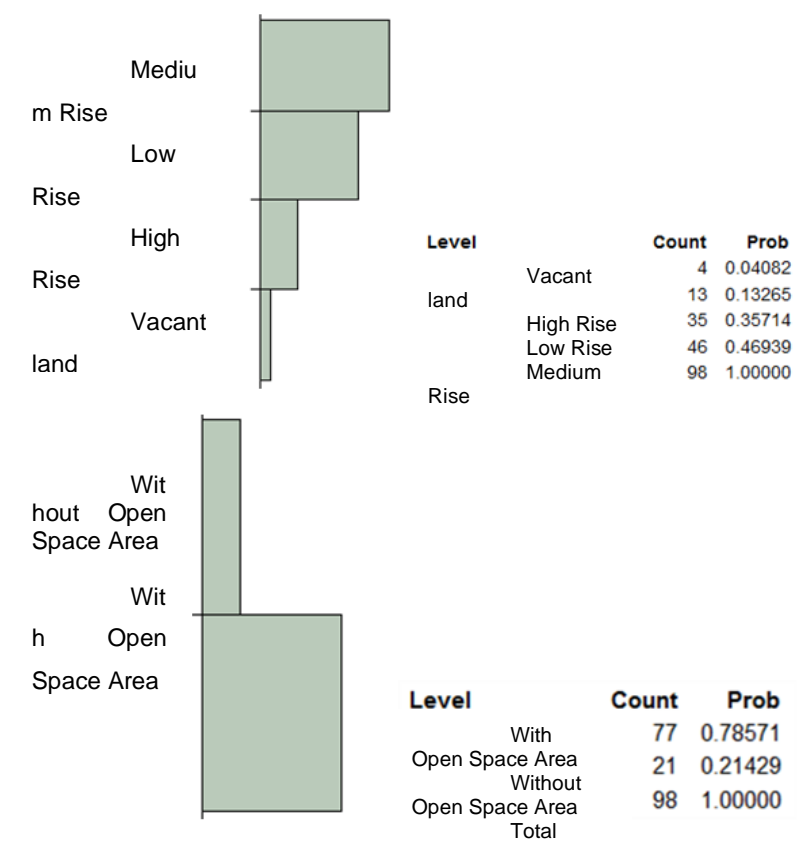

Figure 2. Analysis of the distribution at the height of the building and the existence of the open space on both roads

(Source: researcher analysis)

The dendogram analysis is used to see the correlation between the height of the building and the existence of the open space area on each site on both roads. From this dendogram analysis, it appears that there is a closeness that occurs between the height of the building and the existence of the open space area. The analysis results shown that the availability of the open space area has a close relationship with high rise and medium rise buildings. Meanwhile, for those does not have the open space area is more closely related to low rise buildings. For vacant land area here seems have a fairly distant relation with the open space area availability and unavailability (see Figure 3).

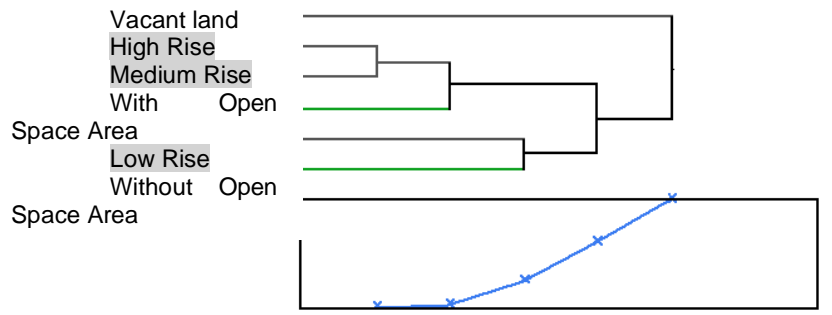

Figure 3. Classification of building heights and the presence of open spaces on both roads through a dendogram (Source: researcher analysis)

From the analysis using the dendogram above, it can be seen that the variables above can be grouped into 2 clusters. The first cluster is a combination of high rise and medium rise variables that has an open space area dominant in each site, then the second cluster is a combination of low rise variables with without open space area variables. The variable of vacant land here cannot be grouped into whether the open space area availability or not, because vacant land does not have definite criteria to explain the existence of the open space area. 


\subsection{Analysis of Physical Conditions on Each Road Section}

With a comprehensive analysis as above, it is also necessary to have more specific analysis on each road section. Because of this, the road section is divided into 2 groups, Jalan Jaksa and Wahid Hasyim. On the Jalan Jaksa (Eastern and Western road section) it has 44 sites that can be analyzed for the correlation between the height of the building and the existence of the open space area. Meanwhile, on the Jalan Wahid Hasyim (North and South road section) it has 54 sites that can be analyzed for the relationship between the height of the building and the existence of the open space area (see Figure 4).

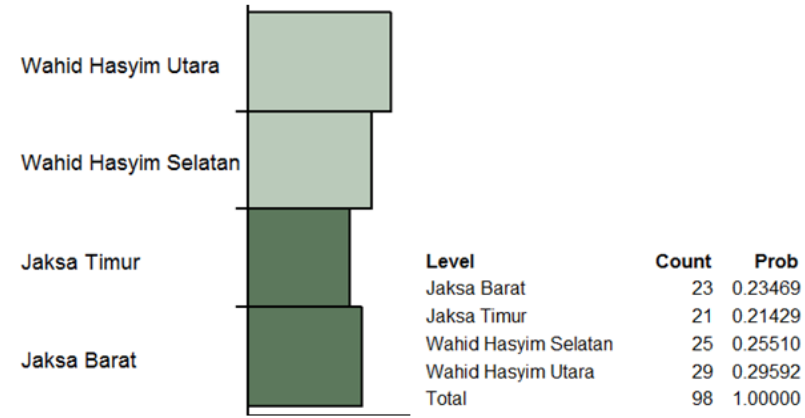

Figure 4. Frequency of the number of buildings contained in both roads through distribution analysis

(Source: researcher analysis)

\subsection{Analysis of the Yard Existence and Building Height on Jalan Jaksa}

The physical conditions on Jalan Jaksa section are shown in the distribution analysis results as below, where low rise buildings dominate more than medium rise and high rise buildings. From 44 sites, there are 20 low rise buildings on this road. While the medium rise buildings on this road section are 15 buildings and the high rise are 5 buildings. There are also 4 vacant lands on the Jalan Jaksa section (see Figure 5). As for the existence of the open space area that can be seen from the results of the analysis on this Jalan Jaksa section, there are 26 sites that has open space area inside and 18 sites that does not (see Figure 5).

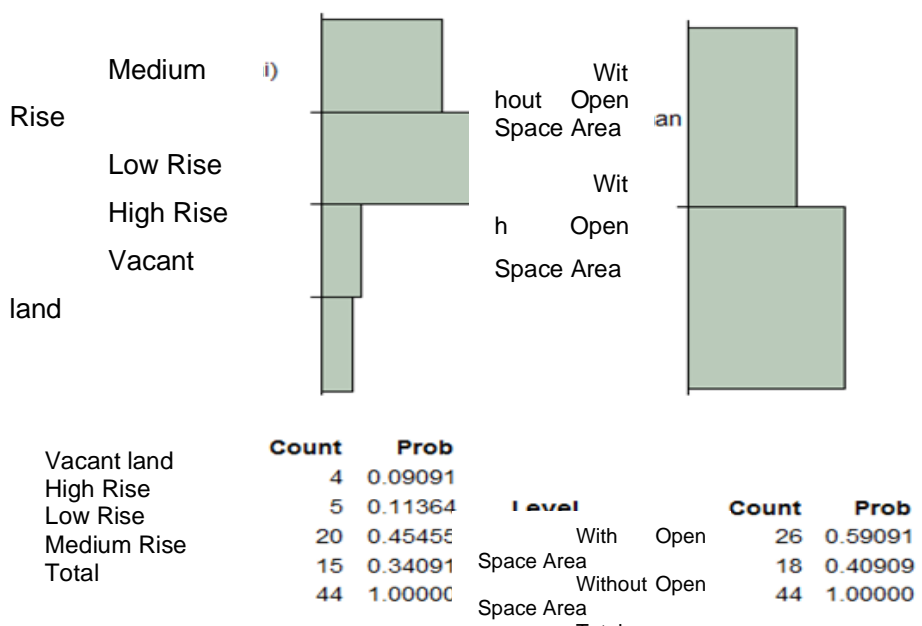

Figure 5. Analysis of distribution on building heights and the preserıce ui uperı spaces on Jalan Jaksa (Source: researcher analysis)

After seeing the results of the distribution analysis above, it can be continued by conducting the dendogram analysis. Based on the data, the results of the analysis shown the grouping of variables into 2 clusters. For the first cluster, it shown that the grouping of vacant land and low rise building are the variable that does not has an open space area, but the low rise buildings are more dominant in the unavailability of the open space area. For the second cluster, the grouping of the high rise and medium rise buildings are the variables that has an open space area on each sites (see Figure 6). 


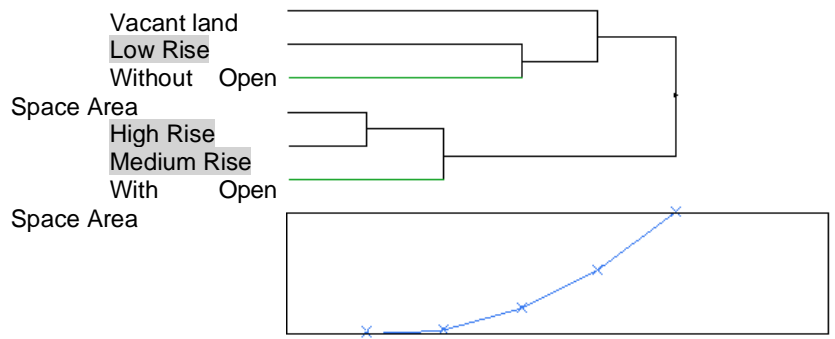

Figure 6. Classification of building heights and the presence of yards on Jalan Jaksa (Source: researcher analysis)

\subsection{Analysis of Building Height and Existence of Yard on Jalan Wahid Hasyim}

While the physical conditions that appear on the big road section (Jalan Wahid Hasyim) can be seen in the distribution analysis results below. From the data of the analysis, it appears that the Wahid Hasyim segment is more dominated by medium rise buildings that compared to low rise and high rise buildings. Medium rise buildings on this road section reached 31 buildings out of a total of 54 buildings. Whereas for low rise buildings it reaches 15 buildings and only 8 buildings of high rise (see Figure 7). For the analysis of the existence of open space area on the Wahid Hasyim section, it is seen from the results of the distribution analysis which shows that the availability of the open space area is more dominant than the unavailability of the open space area. This can be seen from the number of sites that have an open space area inside it reaches 51 sites, while those that are not available them reaches 3 sites (see Figure 7).

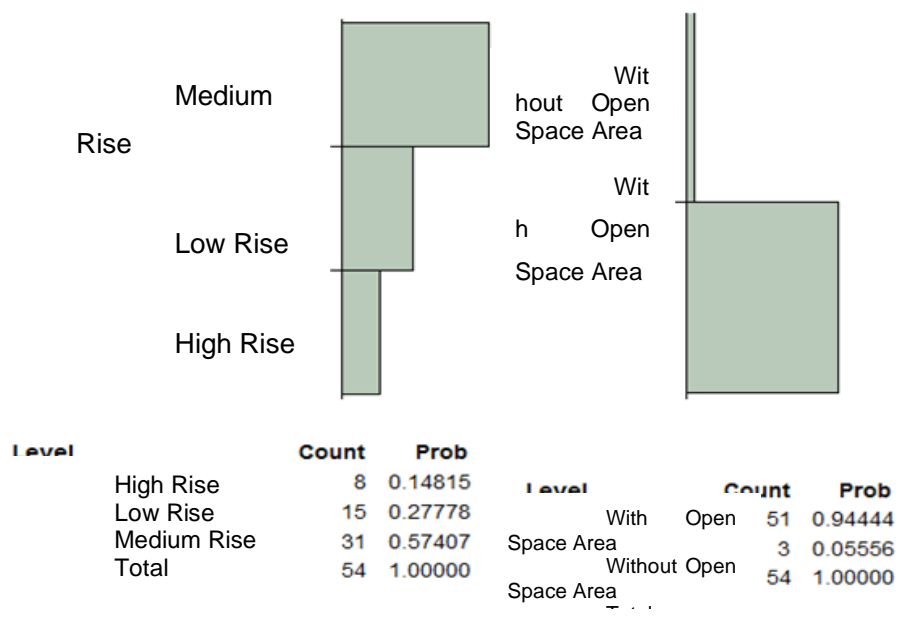

Figure 7. Analysis of distribution on building heights and the presence of yards on Jalan Wahid Hasyim (Source: results of researcher analysis)

From the results of the distribution analysis above, it can be continued by conducting dendogram analysis to see the relationships based on grouping of variables. The results of the data from the dendogram below, indicate the grouping of variables that divided into 2 clusters. For the first cluster, there is a grouping of low rise buildings with the sites that are has not open space area inside. For the second cluster, the high rise and medium rise buildings are grouped with the variable of availability the open space area on each sites. Under these conditions, it can be seen that there is a relationship between the height of the building and the existence of the open space area on each sites (see Figure 8). 


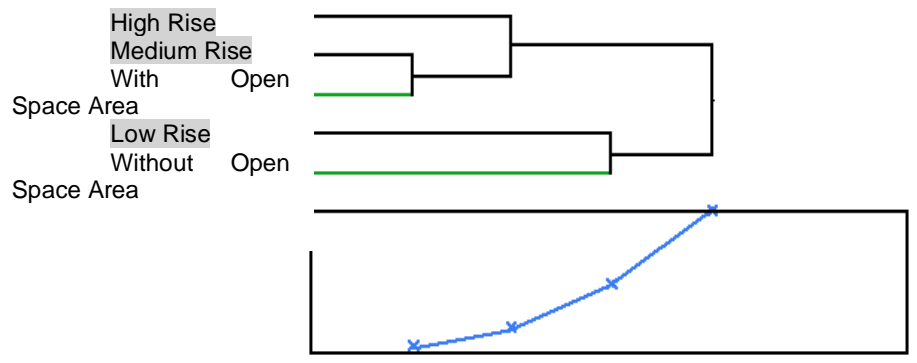

Figure 8. Classification of building heights and the presence of open spaces on Jalan Wahid Hasyim (Source: results of researcher analysis)

As observed from the results of distribution analysis and dendogram analysis on both roads (Jalan Jaksa and Jalan Wahid Hasyim) shows that there are correlation between the height of the building and the existence of the open space area. The correlation can be seen with the height of the building that exceeds low rise buildings ( 1 storey-building) more dominantly has an open space area inside of each sites. This can occur due to several factors, such as the presence of the road border line (GSJ), the building border line (GSB), the amount of capacity (human capacity) and the function of the building itself.

For example, buildings that are dominated by having open space area in their sites are in medium rise and high rise buildings groups (see Figure 10). That is because the functions of the two building groups (medium rise and high rise) has different function than the low rise buildings (see Figure 9) and also accompanied by the ability to accommodate the number of human capacities (building users) which tend to be higher in number compared to low buildings rise.
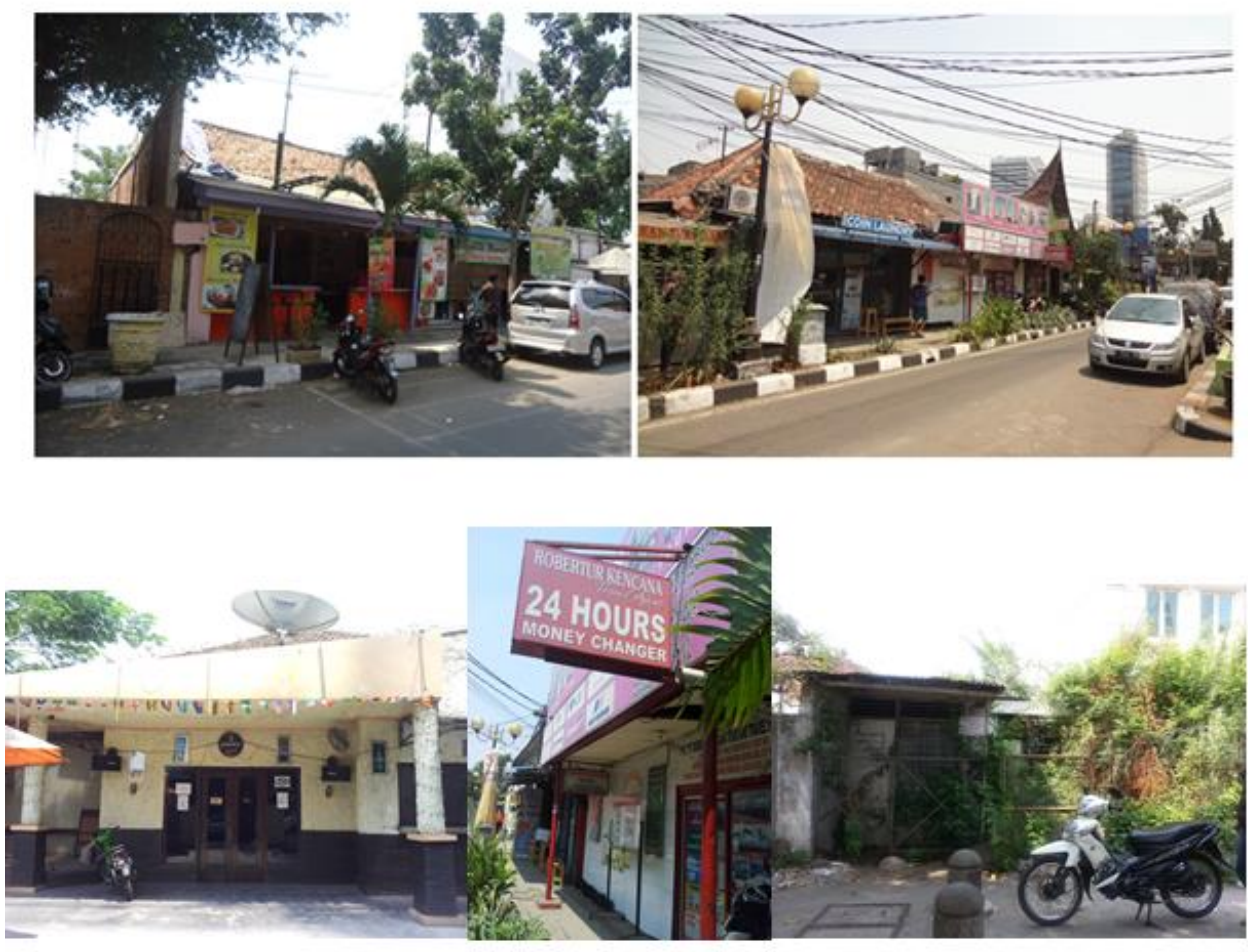

Figure 9. Low rise buildings and vacant lands without an open space area (Source: researcher documentation) 

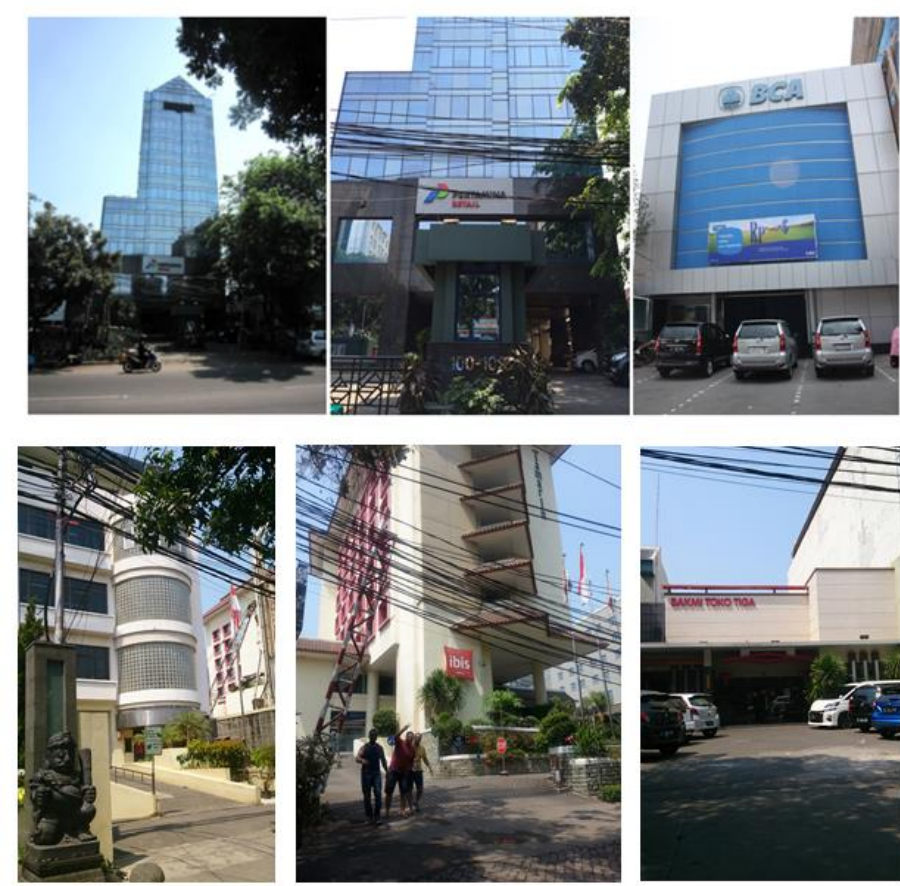

Figure 10. Medium rise and high rise buildings with an open space area (Source: researcher documentation)

Meanwhile, the existence of the road border line (GSJ) and the building border line (GSB) should not be a differentiator in presence of the open space area or not, as well as in high rise buildings, medium rise buildings and low rise buildings.

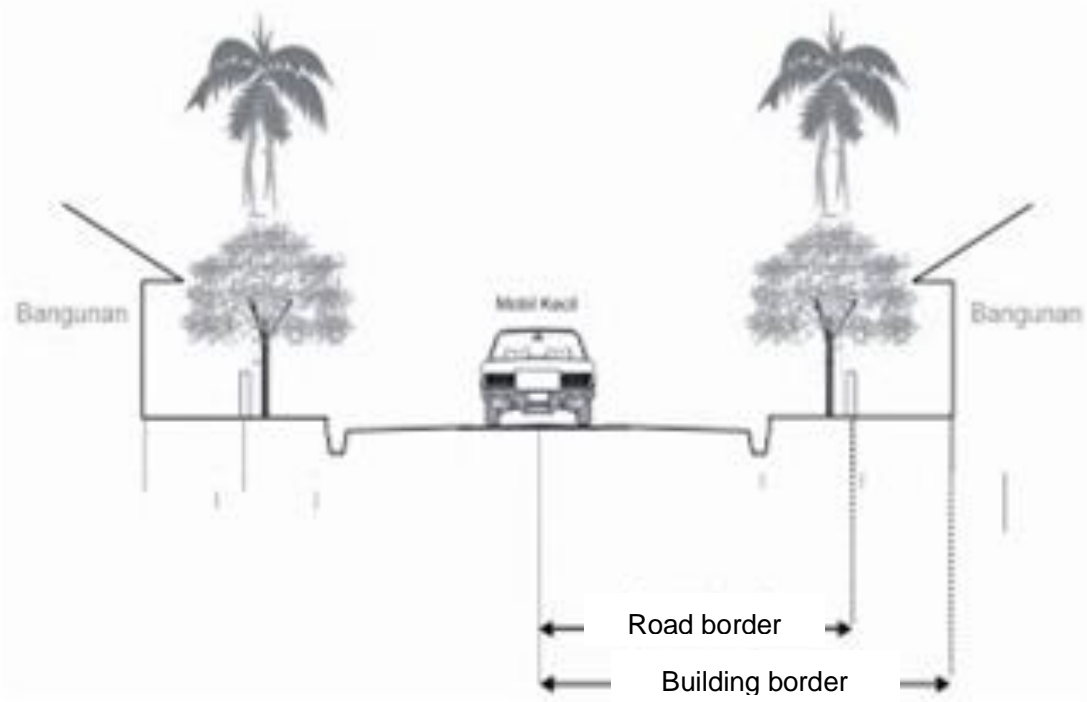

Figure 11. Road border line (GSJ) and building border line (GSB)

(Source: sadedeproperty.blogspot.com, 2018)

As shown in the literature and Figure 11 above, specifically for trade and commercial services areas should be consider the existence of a minimum GSB and the GSJ limit. However, in reality on these two roads, many commercial buildings only have 1 storey which means does not has a road border line (GSJ), building border line (GSB) and even KDB (basic coefficient of building), etc. This can make 
the low rise building dominantly does not have an open space area like the high rise and medium rise buildings.

\section{Conclusions}

Based on the above analysis, it can be seen that there are correlation between "open space area existence" and "building height". In addition, literature sources and building regulations also indicate this correlation. It can be concluded that the buildings should has an open space (yard) whose proportions are adjusted to the height of the building (TB). The proportion of the existence of open space (yard) can also be adjusted by considering the rules of the building border line (GSB), the road border line (GSJ), and so on. These considerations actually shows that the existence of the yard as an open space area in fact is very important to be provided. The yard as an open space can certainly be used to fulfill the needs of human activities, such as parking a vehicle, as an intermediate space, as a green open space, or even can be used for the needs of the gathering point area as an assembly point from disasters that may occur at any time. Suggestions that can be given, is for the owners who do not have a yard (open space) should be rebuilt or redesigned to consider the needs and safety of its own users.

\section{References}

Budiwati, F. 2010. Perencanaan Pemanfaatan Ruang Terbuka Hijau sebagai Kawasan Evakuasi Bencana Gempa Bumi di Kota Padang, Provinsi Sumatera Barat. Skripsi. Departemen Arsitektur Lanskap, Fakultas Pertanian, Institut Pertanian Bogor. Bogor.

Hendrojogi, W. 2008. Arahan Pengaturan dan Pengendalian Bangunan di Kecamatan Pinang Kota Tangerang. Jurnal Sains dan Teknologi Indonesia 10 (1): 62-70.

Iswanto, D. 2006. Kajian Ruang Publik Ditinjau dari Segi Proporsi / Skala dan Enclosure. Jurnal Ilmiah Perancangan Kota dan Permukiman 5 (2): 74-81.

Peraturan Daerah Provinsi Daerah Khusus Ibukota Jakarta Nomor 7 Tahun 1991 Bangunan Dalam Wilayah Daerah Khusus Ibukota Jakarta. 26 Agustus 1991. Lembaran Negara Republik Indonesia Tahun 1991. Jakarta.

Peraturan Daerah Provinsi Daerah Khusus Ibukota Jakarta Nomor 7 tahun 2010 (Revisi 1991) Bangunan Gedung. 3 November 2010. Lembaran Negara Republik Indonesia Tahun 2010 Nomor 7. Jakarta.

Peraturan Kepala Badan Nasional Penanggulangan Bencana Nomor 4 Tahun 2008 Pedoman Penyusunan Rencana Penanggulangan Bencana. Lembaran Negara Republik Indonesia Tahun 2008. Jakarta.

Peraturan Menteri Pekerjaan Umum Nomor: 29/PRT/M/2006 (Revisi 1998) Pedoman Persyaratan Teknis Bangunan Gedung. 1 Desember 2006. Lembaran Negara Republik Indonesia Tahun 2006. Jakarta.

Sadedeproperty. 2015. Mengenal Istilah GSB, GSJ dan Ketinggian Bangunan. http://sadedeproperty.blogspot.com/2015/10/mengenal-istilah-gsb-gsj-dan-ketinggian.html. 20 September 2018.

Shirvani, H. 1985. The Urban Design Process. Van Nostrand Reinhold Company. New York.

Undang-Undang RI Nomor 24 Tahun 2007 Penanggulangan Bencana. 26 April 2007. Lembaran Negara Republik Indonesia Tahun 2007 Nomor 66. Jakarta.

Undang-Undang Republik Indonesia Nomor 26 Tahun 2007 Penataan Ruang. 26 April 2007. Lembaran Negara Republik Indonesia Tahun 2007 Nomor 68. Jakarta. 